\title{
Anti-Herpes Simplex Viruses activity of Camellia sinensis, member of the family Theaceae (green tea)
}

Govindharaj Deepika, Hariharan Durgadevi, Rohan Narayan, Munisamy Sudanthira, Elanchezhiyan Manickan*

From 2nd International Science Symposium on HIV and Infectious Diseases (HIV SCIENCE 2014)

Chennai, India. 30 January - 1 February 2014

\section{Background}

Medicinal plants were shown to possess several bioactivities of which Camellia sinensis, a popularly used refreshing beverage has been reported to have immune modulating and anti viral activities. From our lab we had already shown that $C$. sinensis extracts possessed anti-HIV and anti-HBV activities. In the current study we evaluated its anti-HSV activities.

\section{Methods}

Aqueous and methanolic extracts of $C$. sinensis were tested for their anti-HSV property by CPE reduction assay on Vero cell monolayers. Cytotoxicity of the extract was measured by MTT assay.

\section{Results}

Experiments showed that $12 \mu \mathrm{g} / \mathrm{mL}$ concentration of C. sinensis completely inhibited HSV-1 and 2 and the drug was found to be non toxic up to $10 \mathrm{mg} / \mathrm{mL}$.

\section{Conclusion}

The study showed that C.sinesis extracts and EGCG compound are potent inhibitor of both HSV-1 and HSV-2 infection and it was found to be relatively non toxic.
* Correspondence: emanickan@yahoo.com

Department of Microbiology, Dr. ALM PG IBMS, University of Madras, Chennai, India
Published: 27 May 2014

\section{doi:10.1186/1471-2334-14-S3-P47}

Cite this article as: Deepika et al:: Anti-Herpes Simplex Viruses activity of Camellia sinensis, member of the family Theaceae (green tea). BMC Infectious Diseases 2014 14(Suppl 3):P47.
Submit your next manuscript to BioMed Central and take full advantage of:

- Convenient online submission

- Thorough peer review

- No space constraints or color figure charges

- Immediate publication on acceptance

- Inclusion in PubMed, CAS, Scopus and Google Scholar

- Research which is freely available for redistribution

\section{() Biomed Central}

